\title{
Ground-Water Quality in Selected Areas of Wisconsin
}

S. M. HINDALL

U. S. GEOLOGICAL SURVEY

Water-Resources Investigations

Open-File Report 79-1594

Prepared in cooperation with the

Wisconsin Department of Natural Resources

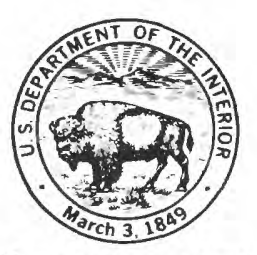

December 1979 


\title{
UNITED STATES DEPARTMENT OF THE INTERIOR
}

\author{
CECIL D. ANDRUS, SECRETARY
}

\section{GEOLOGICAL SURVEY}

H. William Menard, Director

This report was prepared in cooperation with the Wisconsin Department of Natural Resources. Thanks are given the many officials, State agencies, and individual well owners who assisted this study by providing access to their wells for collecting water samples.

For additional information write to:

U. S. Geological Survey

1815 University Avenue

Madison, Wisconsin 53706 


\section{CONTENTS}

Page

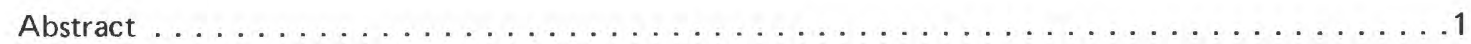

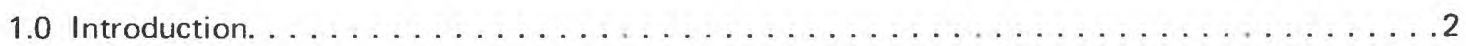

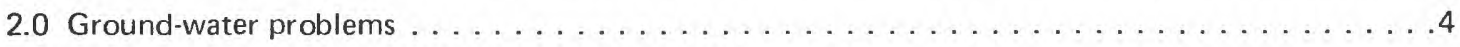

3.0 Ground-water sampling. . . . . . . . . . . . . . . . . . . .

4.0 Selected areas in Wisconsin having problems with ground-water quality $\ldots \ldots \ldots \ldots \ldots$

4.1 Prairie Lake Township, Barron County . . . . . . . . . . . . . . . 8

4.2 Marinette area, Marinette County . . . . . . . . . . . . . . . . . . . . 10

4.3 Ladysmith area, Rusk County . . . . . . . . . . . . . . . . . . . . 12

4.4 Near Fort Atkinson, Jefferson County. . . . . . . . . . . . . . . . . . . 14

4.5 Near Kellner, Portage County . . . . . . . . . . . . . . . . . . . . 16

4.6 Armenia Township, Juneau County . . . . . . . . . . . . . . . . . 18

References. . . . . . . . . . . . . . . . . . . . . . . . . . . 20 



\title{
Ground-Water Quality in Selected Areas of Wisconsin
}

\author{
S. M. HINDALL
}

\begin{abstract}
Analysis of 2,071 ground-water samples from 970 wells throughout Wisconsin indicate large variations in ground-water quality. Ground water in Wisconsin is generally suitable for most uses, but in some areas concentrations of chemical constituents

exceed recommended drinking-water standards. Iron, manganese, and nitrate commonly exceed recommended drinking-water standards and dissolved solids, sulfate, heavy metals, and phenolic materials may present local problems.
\end{abstract}




\title{
1.0 INTRODUCTION
}

\section{WATER SAMPLES WERE COLLECTED FROM FIVE AQUIFERS IN WISCONSIN}

\author{
Ground water in Wisconsin is predominately \\ of the calcium magnesium bicarbonate type
}

\begin{abstract}
Water samples were collected from wells tapping the sand-and-gravel, Silurian dolomite, Maquoketa, sandstone, and Precambrian aquifers. On the basis of mean concentrations of constituents, calcium comprises from 43 percent of the cations in water from the Precambrian aquifer to 61 percent in water from the Maquoketa aquifer. Magnesium comprises from 28 percent of the cations in water from the Precambrian aquifer to 39 percent in water from the sand-and-gravel aquifer. Bicarbonate comprises from
\end{abstract}

76 percent of the anions in water from the sand-andgravel aquifer to 49 percent in water from the Silurian dolomite aquifer. Sulfate comprises 49 percent of the anions in water from the Maquoketa aquifer.

The purpose of this report is to describe briefly the chemical quality of ground water in Wisconsin and to discuss representative water-quality problems in six areas. 


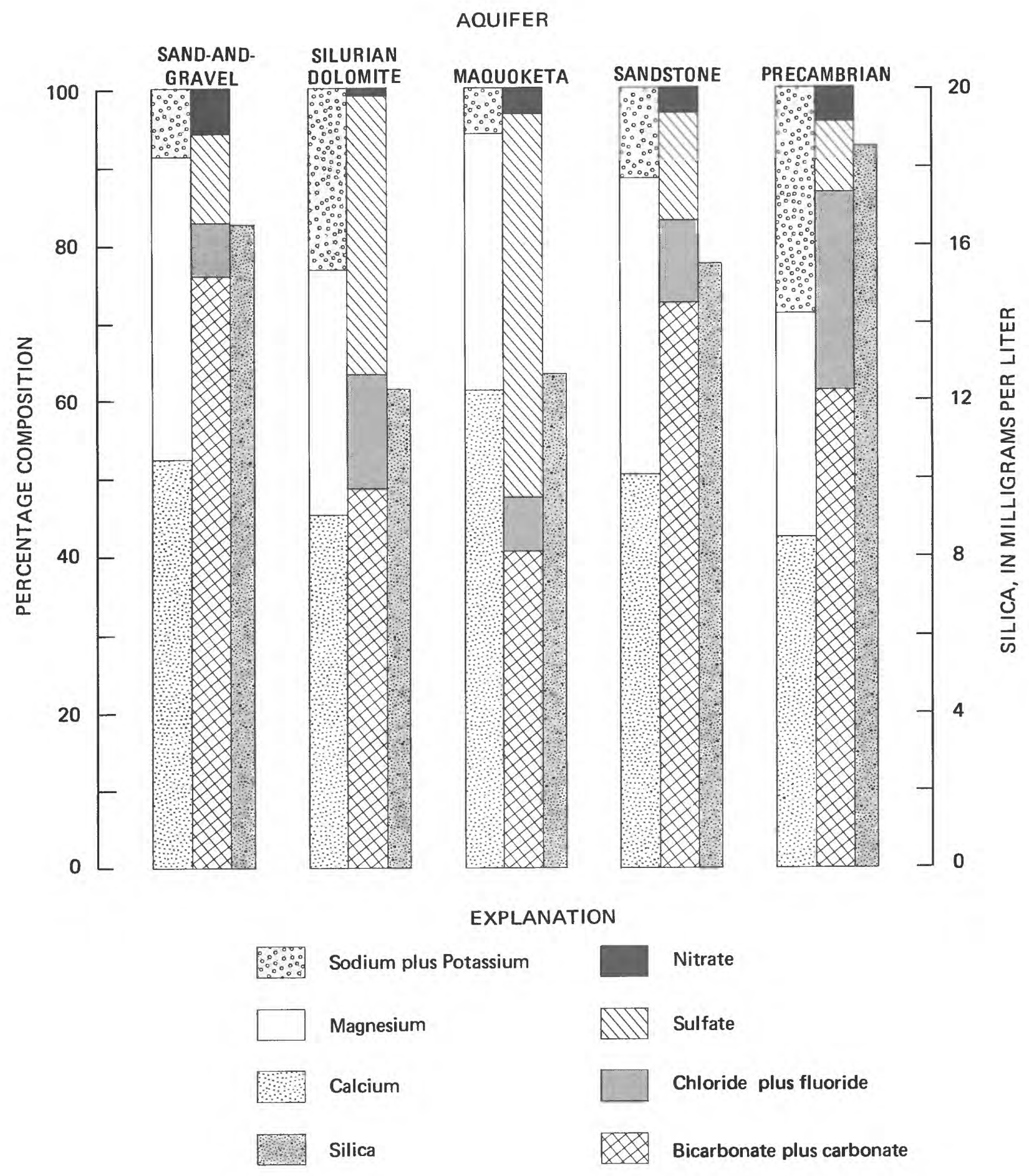

Mean composition of ground water in Wisconsin. 


\title{
2.0 GROUND-WATER PROBLEMS
}

\section{SOME PARTS OF WISCONSIN HAVE POTENTIAL PROBLEMS RELATED TO GROUND-WATER QUALITY}

\author{
2,071 analysis of water samples from 970 wells \\ throughout Wisconsin indicate large variations \\ in ground-water quality
}

Much variation in ground-water quality, both within individual aquifers and between different aquifers, is shown by the maximum and minimum values of selected constituents. Water from the sandstone aquifer generally has the greatest range in values, whereas that from the Precambrian aquifer generally has the least. There are not enough analyses of water from the Maquoketa aquifer for a valid statistical analysis. The results of the analyses were compared to mean values for Wisconsin and to drinking-water standards to determine if the water exceeded recommended or mandatory standards, thereby defining a potential problem area.

Recommended and mandatory drinking-water standards (Environmental Protection Agency, 1976) and water-quality criteria for other uses (California State Water Quality Control Board, 1963) are shown below. Ground water in Wisconsin is generally hard, and concentrations of arsenic, chloride, chromium, copper, fluoride, iron, lead, manganese, nitrate, phenolic materials, and dissolved solids exceed drinking-water standards in water from some aquifers.

Concentrations in micrograms per liter except chloride, fluoride, nitrate, sulfate, and dissolved solids in milligrams per liter

DRINKING WATER

Arsenic
Cadmium
Chloride
Chromium
Copper
Fluoride
Iron
Lead
Nitrate
Phenols
Selenium
Sulfate
Zinc
Dissolved solids

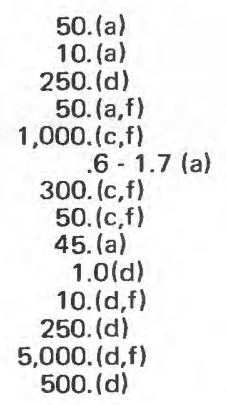

FRESH-WATER AQUATIC ORGANISMS

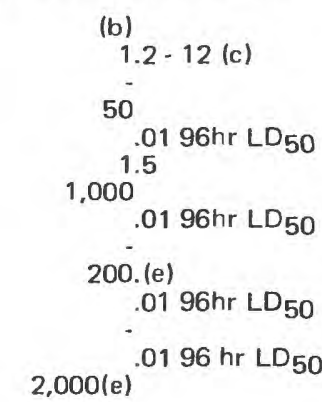

LIVESTOCK IRRIGATION

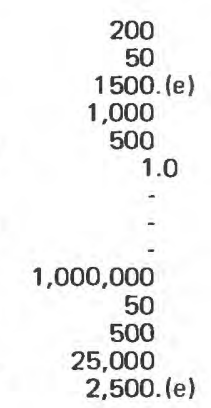

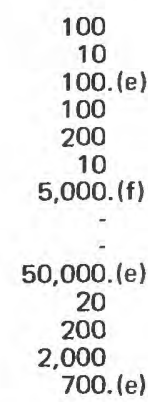

(a), mandatory limit; (b), drinking-water standard protective; (c), lower limit for salmonid fish in hard water, higher limit for less sensitive organisms; (d), recommended limit; (e), concentration normally not detrimental to use; (f), traces essential to nutrition 


\title{
WATER FROM 107 WELLS WAS SAMPLED IN 59 POTENTIAL PROBLEM AREAS THROUGHOUT THE STATE
}

\author{
Ground water in Wisconsin is generally of suitable \\ quality for most uses, but in some areas concen- \\ rations of various chemical constituents are \\ high enough to be considered a problem
}

\begin{abstract}
Water-quality problems, either natural or the result of man's activities, occur in all parts of the State and in all aquifers. From interpretation of data from 107 sampled wells, 59 areas (upper map) in Wisconsin were selected for further water-quality sampling because they had known or suspected problems, were susceptible to problems, or were areas where little or no data are available. Water samples were collected in these areas during 1976 and 1977. The results of analyses of these samples are published in "Water Resources Data for Wisconsin, 1976" and "Water Resources Data for Wisconsin, 1977" Where possible,
\end{abstract}

several wells in an area were sampled. Each sampled well was finished at a different depth or in a different aquifer. Potential problems in water from about half of the 107 sampled wells were revealed. Iron, manganese, and nitrate are the three constituents whose concentrations most commonly exceed recommended or mandatory drinking-water standards. High concentrations of dissolved solids, sulfate, arsenic, and phenolic materials may present local problems. Of the 59 areas, 6 (lower map) were selected for further study and as being representative of Wisconsin water problems. 


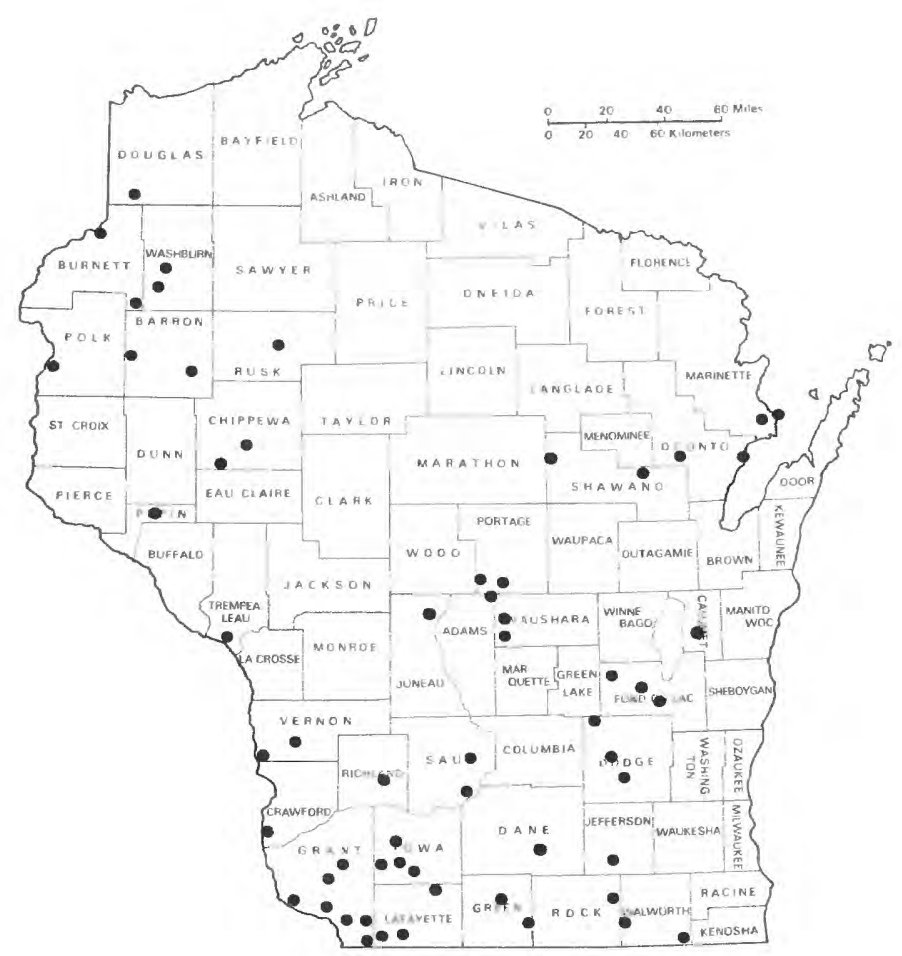

Ground-water sampling sites in potential problem areas.

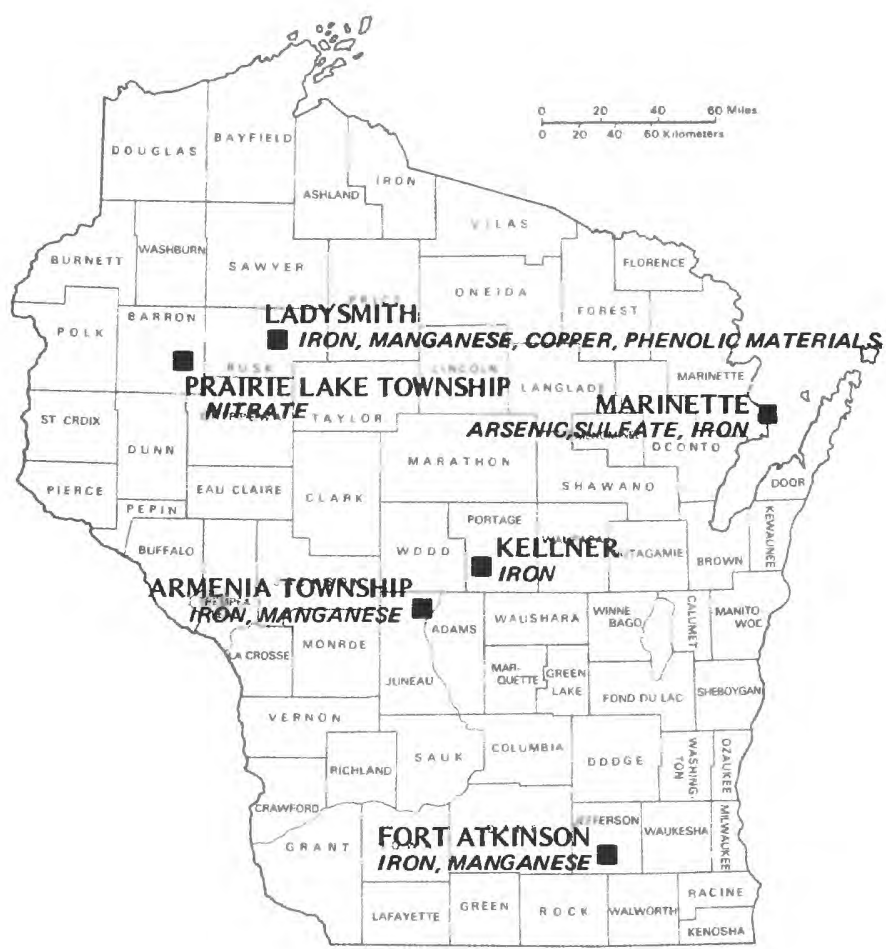

Location of selected areas with representative problem constituents. 


\title{
4.0 SELECTED AREAS IN WISCONSIN WITH GROUND-WATER-QUALITY PROBLEMS
}

\subsection{Prairie Lake Township, Barron County}

\section{NITRATE IN GROUND WATER}

\author{
Concentrations or nitrate exceeding recommended drinking-water \\ standards were found in ground water from three wells \\ within a heavily irrigated section.
}

\begin{abstract}
Although the ground water in Barron County is generally suitable for most uses, the nitrate-nitrogen concentration of some ground water in the county makes it unsuitable for drinking. Concentrations of nitrate exceeding the $45 \mathrm{mg} / \mathrm{L}$ (milligrams per liter) (10 $\mathrm{mg} / \mathrm{L}$ as nitrogen) limit set for drinking water were found in the water from three wells in a section south of Cameron. Measured concentrations of nitrate nitrogen in the ground water from these wells ranged from 11 to $23 \mathrm{mg} / \mathrm{L}$. This is an area of intensive irrigation that uses the shallow ground water from the sand-and-gravel aquifer in Red Cedar River valley. It is highly unlikely that natural sources such as soil, rocks, or the atmosphere account for the high concentrations of nitrate in this area.
\end{abstract}

Application of fertilizers and heavy irrigation may cause unused and untrapped nitrogen to percolate downward to the shallow aquifer. Over the years, nitrogen concentrations in many irrigated areas appear to have stabilized at a level above the statewide average and will probably remain so until farming practices change.

The map shows the local nature of the recharge to and discharge from the ground-water system in this area south of Cameron. The system is recharged between the Red Cedar River and Prairie Lake and discharges either to the lake or river. The extremely short ground-water-flow paths in this area indicate that the source of nitrate is local.

High nitrate-nitrogen concentrations in ground water in areas of intensive irrigation is not unique to Barron County and is common in some other irrigated areas of the State. 


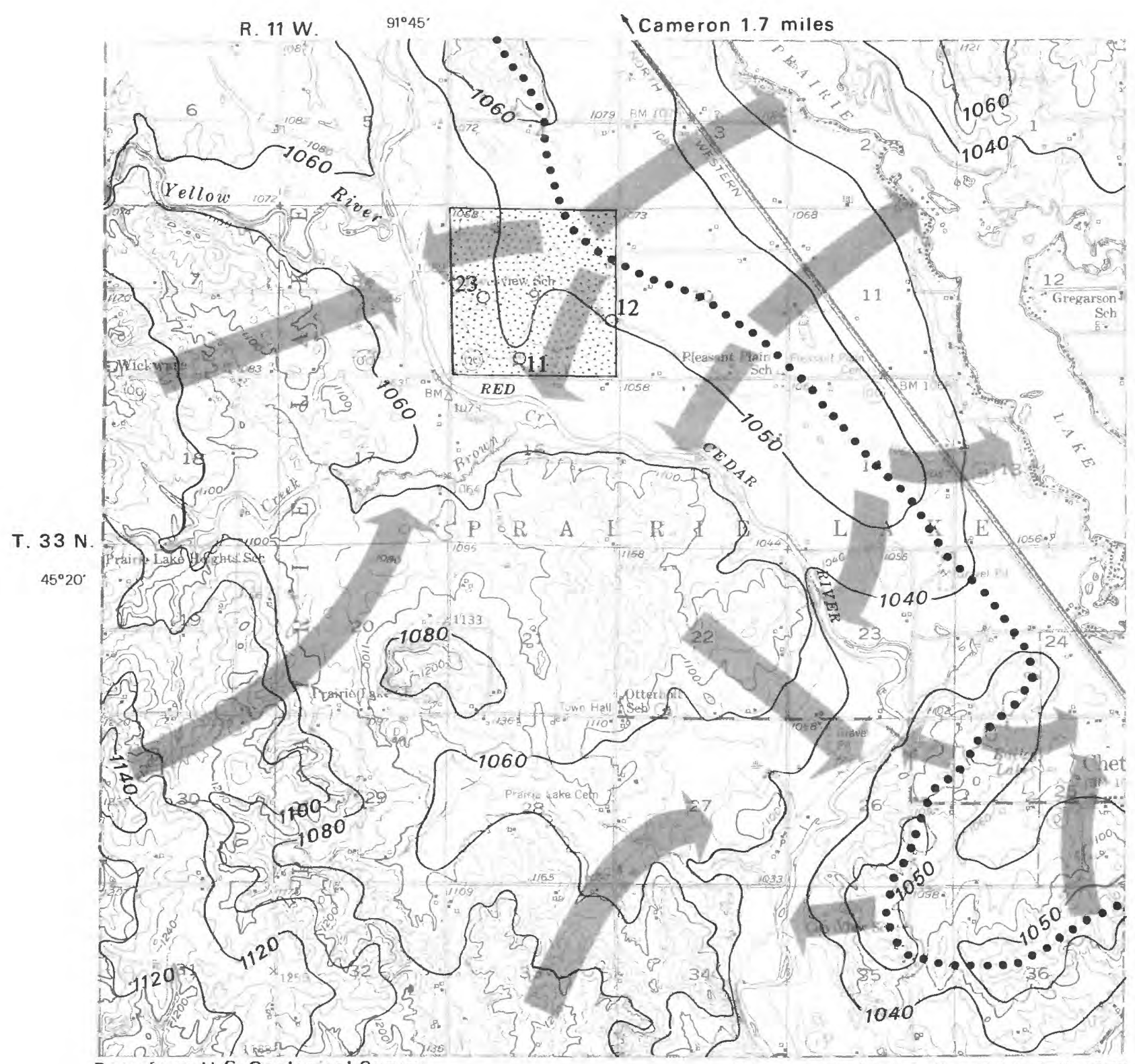

Base from U.S. Geological Survey

Barron and Chetek 1:62,500, 1951

Water-table from Bell and Hindall, 1975 \begin{tabular}{llll}
0 & $1 / 2$ & 1 & 2 \\
\hline
\end{tabular}

\section{EXPLANATION}

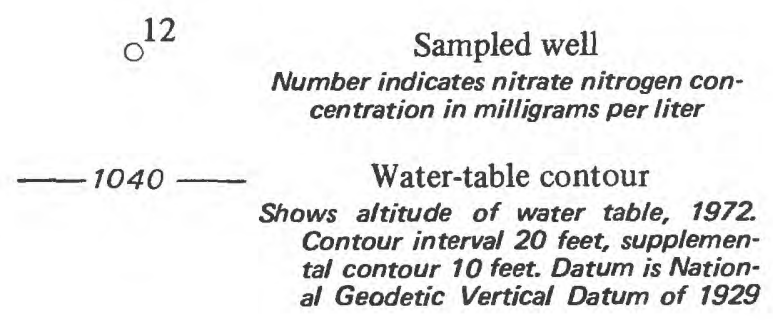

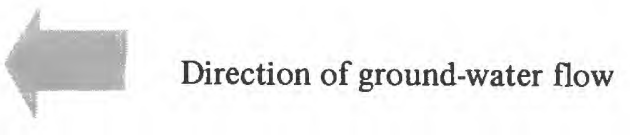

Area of intensive study

- Ground-water divide

Nitrate nitrogen in ground water in Prairie Lake Township, Barron County. 


\title{
4.2 Marinette area, Marinette County
}

\section{ARSENIC, SULFATE, AND IRON IN GROUND WATER}

\author{
Concentrations of arsenic, sulfate, and iron that exceede recommended drinking- \\ water standards were found in ground water. The concentration of arsenic \\ results from man's activities, whereas the sulfate and iron concentrations \\ appear to be natural.
}

The general direction of ground-water movement in the Marinette area in the sand-and-gravel and sandstone aquifers is from west to east. Thus, contaminated ground water moves eastward. Arsenic, in concentrations as much as $250 \mu \mathrm{g} / \mathrm{L}$ (micrograms per liter), is confined to a narrow zone along the Menominee River. The arsenic concentrations will decrease as the aquifer is flushed out by recharge. The source of arsenic, which is being eliminated, was a pile of exposed chemical-manufacturing waste. Naturally occurring pyrite and gypsum in the sandstone aquifer probably are the sources of sulfates and iron in the ground water. 


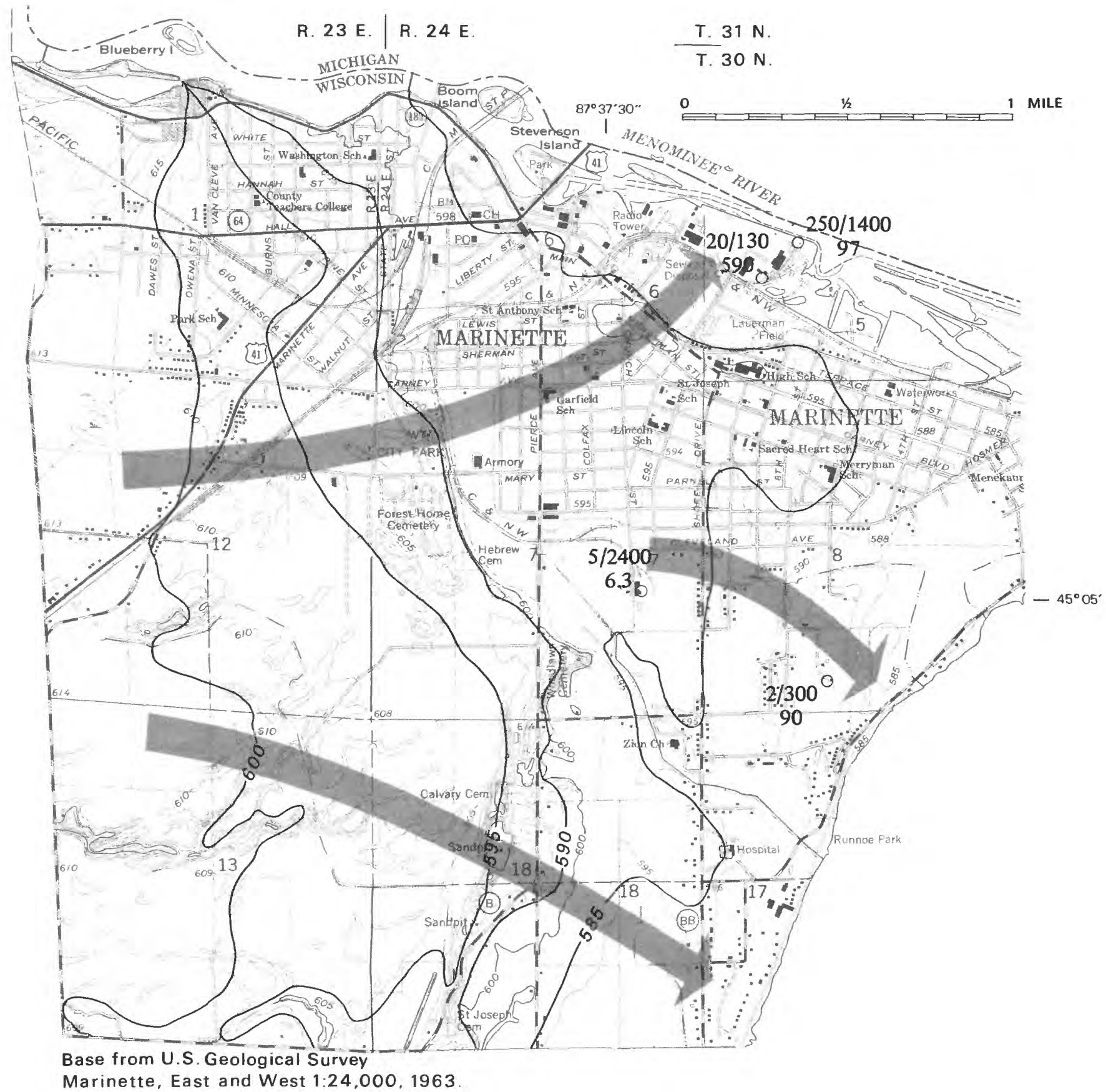

EXPLANATION

$20 / 130$

○ 590

Sampled well

Number indicates arsenic/iron concentrations, in micrograms per liter, and sulfate concentration in milligrams per liter, respectively

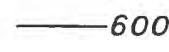

600

Water-table contour Shows altitude of water table, July

1977. Contour interval 5 feet. Datum is National Geodetic Vertical Datum of 1929

Direction of ground-water flow

Arsenic, iron, and sulfate in ground water near Marinette, Marinette County. 


\title{
4.3 Ladysmith area, Rusk County
}

\section{IRON, INANGANESE, AND PHENOLIC MATERIALS IN GROUND WATER}

\author{
Concentrations of iron, manganese, and phenolic materials that exceede recommended \\ drinking-water standards were found in ground water. These concentrations are \\ probably from natural sources
}

The problem of iron and manganese concentrations in ground water in excess of recommended drinking-water standards is random throughout Rusk County. Four of the seven wells sampled for iron and five of seven wells sampled for manganese had concentrations that exceede the standards. The maximum measured concentration of iron and manganese was 14,000 and $650 \mu \mathrm{g} / \mathrm{L}$, respectively. The problem is not limited to a single aquifer. The source of the iron and manganese is probably the aquifer itself, but highly organic soils also may contribute significant amounts of these constituents to the ground-water system.

\begin{abstract}
Phenolic materials were detected in concentrations ranging from 1 to $3 \mu \mathrm{g} / \mathrm{L}$ in water samples from four of seven wells sampled in the area. Concentrations greater than $1 \mu \mathrm{g} / \mathrm{L}$ impart tastes to water. The source of the phenolic materials in the Ladysmith area is probably decaying vegetation. The many wetlands in the Ladysmith area shown on the map contain organic soils and provide conditions that promote rapid decay.
\end{abstract}




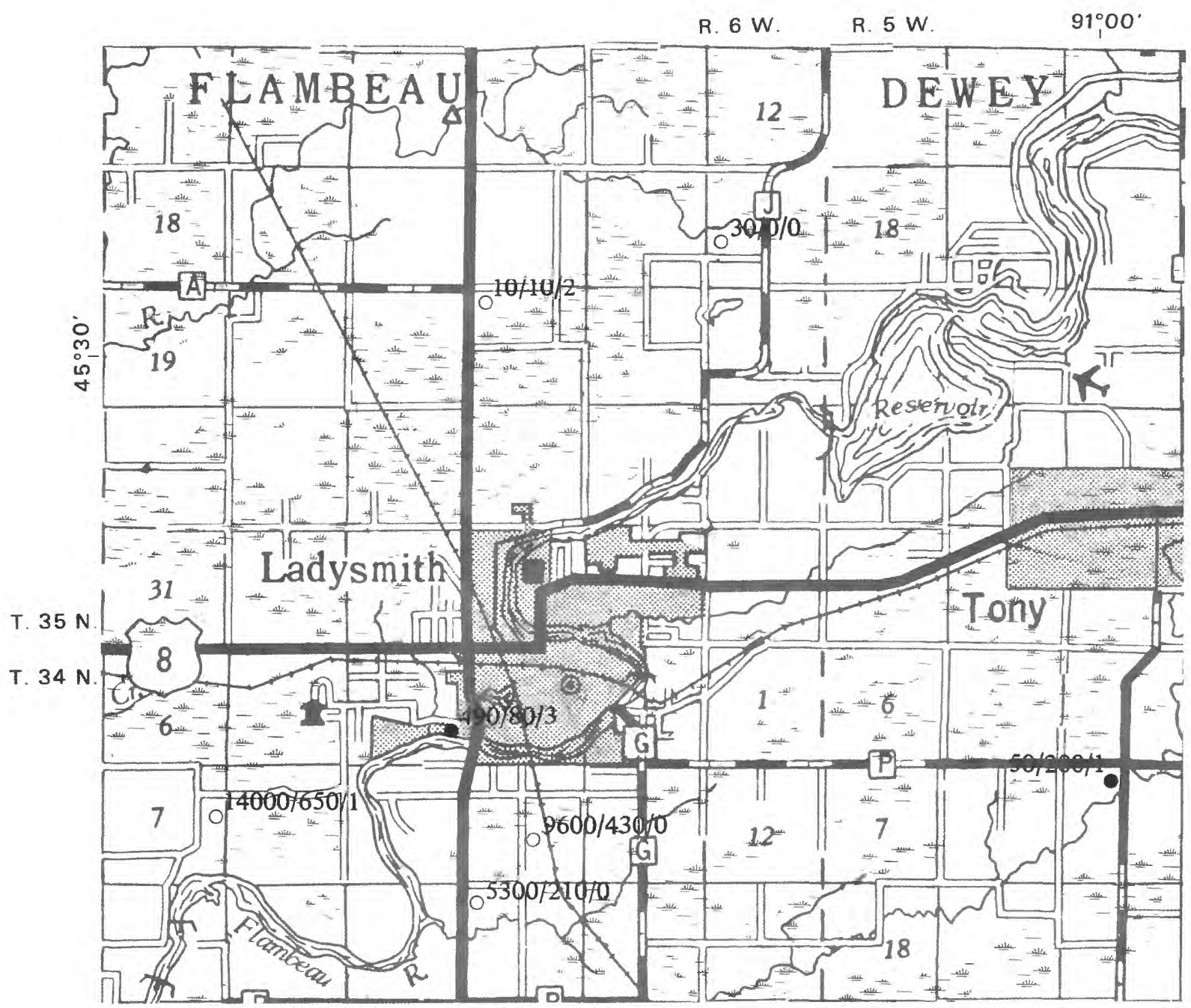

Base from Wisconsin Department of Transportation county highway map, 1:126.720

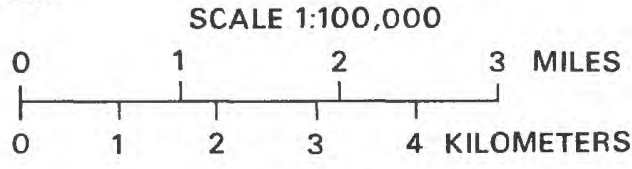

EXPLANATION

- $0^{10 / 10 / 2} \quad$ Sampled well

Number indicates iron/manganese/phenolic materials concentrations, respec. tively, in micrograms per liter. Solid indicates well finished in the sandstone aquifer, open indicates well finished in the sand-and-gravel aquifer

Iron, manganese, and phenolic materials in ground water near Ladysmith, Rusk County. 


\subsection{SELECTED AREAS IN WISCONSIN HAVING PROBLEMS WITH GROUND-WATER QUALITY--Continued}

\subsection{Near Fort Atkinson, Jefferson County}

\section{IRON AND MANGANESE IN GROUND WATER}

Iron and manganese in water may be a problem

in more than one aquifer within the same area

Iron and manganese in some ground water in Jefferson County make it unsuitable for domestic or industrial uses. In a small area east of Fort Atkinson, concentrations of iron in water from five wells ranged from 280 to $3,500 \mu \mathrm{g} / \mathrm{L}$, and the range of manganese concentrations was 60 to $200 \mu \mathrm{g} / \mathrm{L}$. One well was finished in the sand-and-gravel aquifer and the others in the sandstone aquifer. This area near Fort Atkinson is typical of many in the State where concentrations of iron and manganese in ground water are a problem.

The source of most iron and manganese in ground water is the rock and soil material through which the water moves, but decaying organic debris may also be a source of iron. The map at the right shows the direction of water movement in the sand-and-gravel aquifer and shallow sandstone aquifer and the concentrations of iron and manganese. Ground water recharged in the area east of Fort Atkinson discharges locally. Water recharged in the central part of the area discharges to the Rock and Bark Rivers. The short flow paths of the ground water indicate that the source of the iron and manganese is local. 


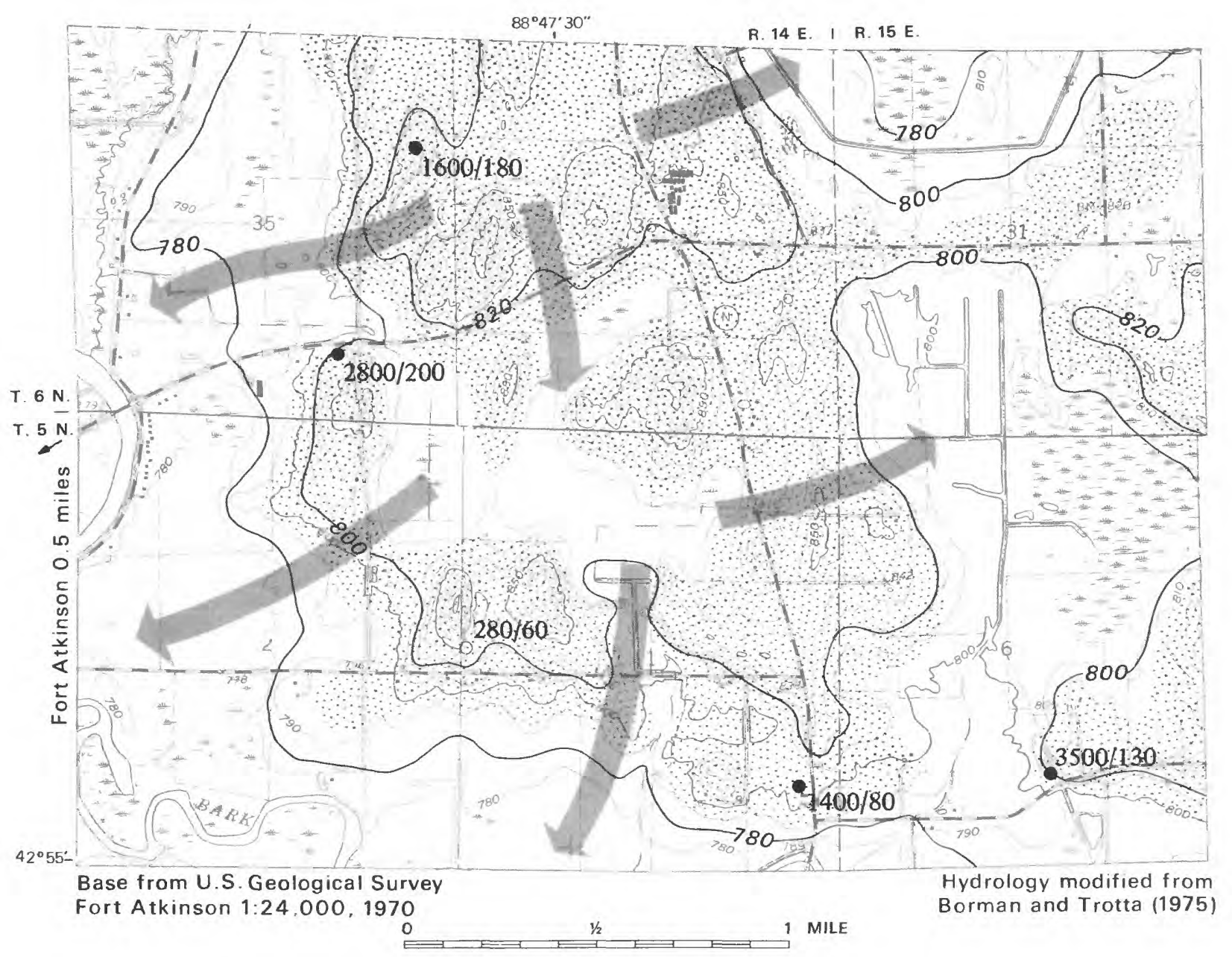

EXPLANATION

\begin{abstract}
- $0^{1400 / 80} \quad$ Sampled well
Number indicates iron/manganese concentrations, respectively, in micrograms per liter. Solid indicates well finished in the sandstone aquifer, open indicates well finished in the sand-and-gravel aquifer
\end{abstract}

Direction of ground-water flow

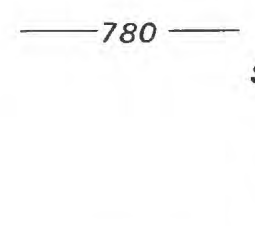

$\therefore$

\begin{abstract}
Water-table contour
Shows altitude of water table, July 1977. Contour interval 20 feet. Datum is National Geodetic Vertical Datum of 1929
\end{abstract}

Area where the depth to water is less than 10 feet 


\subsection{SELECTED AREAS IN WISCONSIN HAVING PROBLEMS WITH GROUND-WATER QUALITY--Continued}

\subsection{Near Kellner, Portage County}

\section{IRON IN GROUND WATER}

Iron in ground water may present a problem in heavily vegetated marshy areas. Concentrations of iron exceeding recommended drinking-water standards were measured in water from several wells within three adjoining square-mile sections.

In Portage County, iron concentrations that exceed recommended drinking-water standards were found in ground water. One well may draw water having high iron concentrations, whereas an adjacent well finished in the same aquifer may not. This situation prevails near Kellner and is typical of many other areas in the State.

Iron is an essential element in both plant and animal metabolism, and therefore is to be expected in organic waste and in plant debris in soils. Decaying plant debris forms weak acids that dissolve iron from the soil and rocks.
The area near Kellner (right) is heavily vegetated and has highly organic soils and a shallow water table. The concentrations of iron in ground water (as much as $16,600 \mu \mathrm{g} / \mathrm{L}$ ) are generally high where aquifers are recharged through noncultivated forest lands. Concentrations are much lower $(400 \mu \mathrm{g} / \mathrm{L})$ where aquifers are recharged through cultivated areas or pasture land. These data indicate that organic material contributes to high iron concentrations in ground water. 


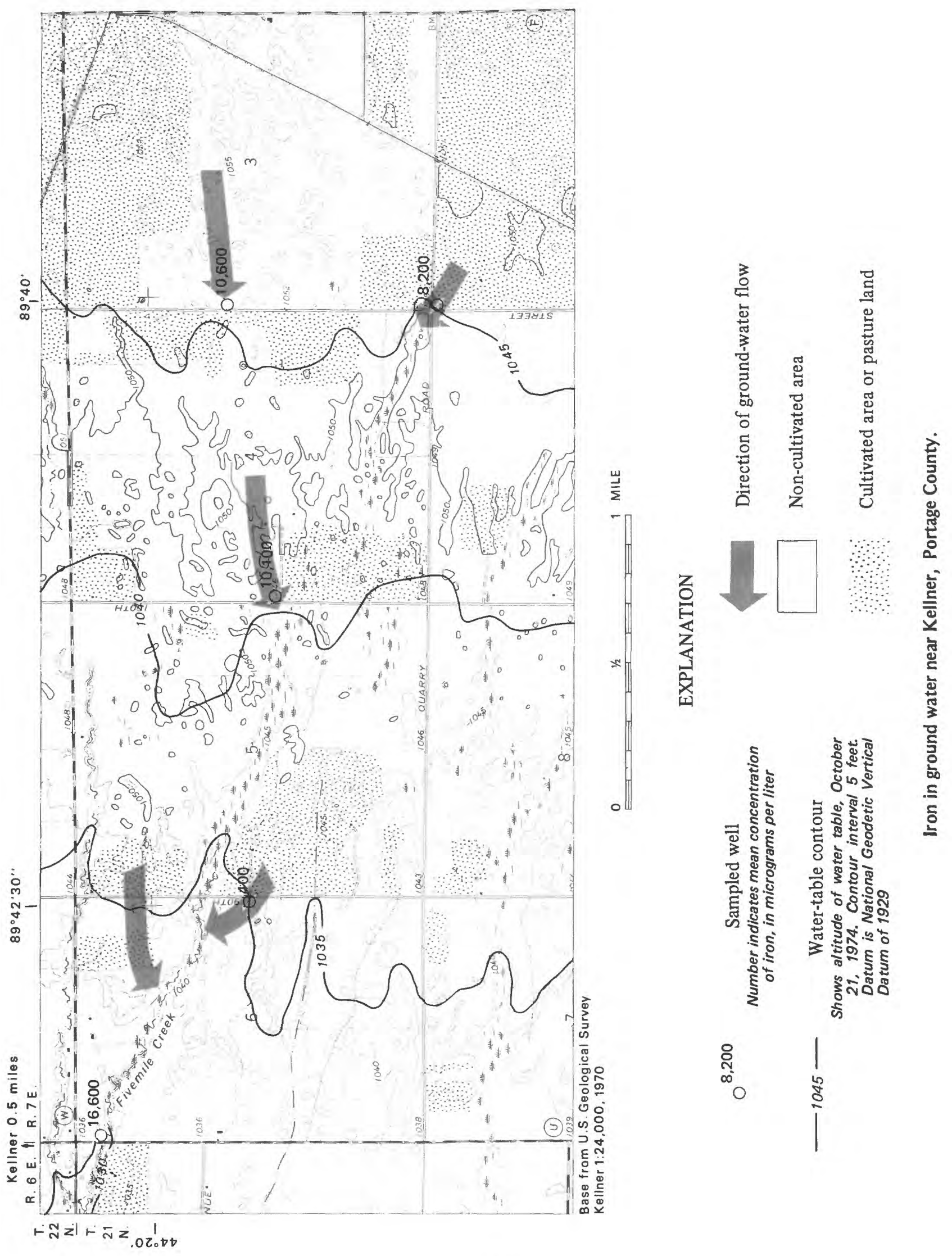




\title{
4.0 SELECTED AREAS IN WISCONSIN HAVING PROBLEMS WITH GROUND-WATER QUALITY--Continued
}

\author{
4.6 Armenia Township, Juneau County
}

\section{IRON AND MANGANESE IN GROUND WATER}

\author{
Iron and manganese in ground water may present problems where \\ forest land is being cleared for development
}

Ground water having iron and maganese concentrations that exceed recommended drinking-water standards is a problem locally in Armenia Township. One such place is where land is being cleared for irrigated farmland. The area is level, has a plentiful water supply from the sand-and-gravel aquifer, and is covered with soils suitable for irrigation. Before irrigation, it was heavily forested with pine and scrub oak. Since 1965, about one-third of it has been cleared and irrigated.

Where the water table was near to the land surface, ditches were dug for drainage. The water-table map also shows the areas cleared for irrigation since 1969 , location of irrigation wells, and the drainage ditch dug in 1976.
Most of the iron and manganese in the ground water of Armenia Township is a result of the highly organic soils. Both iron and manganese are essential elements in plant metabolism and are expected in organic wastes and plant debris. Iron concentrations in water from the two wells sampled in the area were 3,100 and $530 \mu \mathrm{g} / \mathrm{L}$, and the concentrations of manganese were 180 and $60 \mu \mathrm{g} / \mathrm{L}$.

Armenia Township is on the ground-water divide between the Wisconsin and Yellow Rivers. The local source of water and the short distance between recharge and discharge points confirm that iron and manganese are derived locally. 


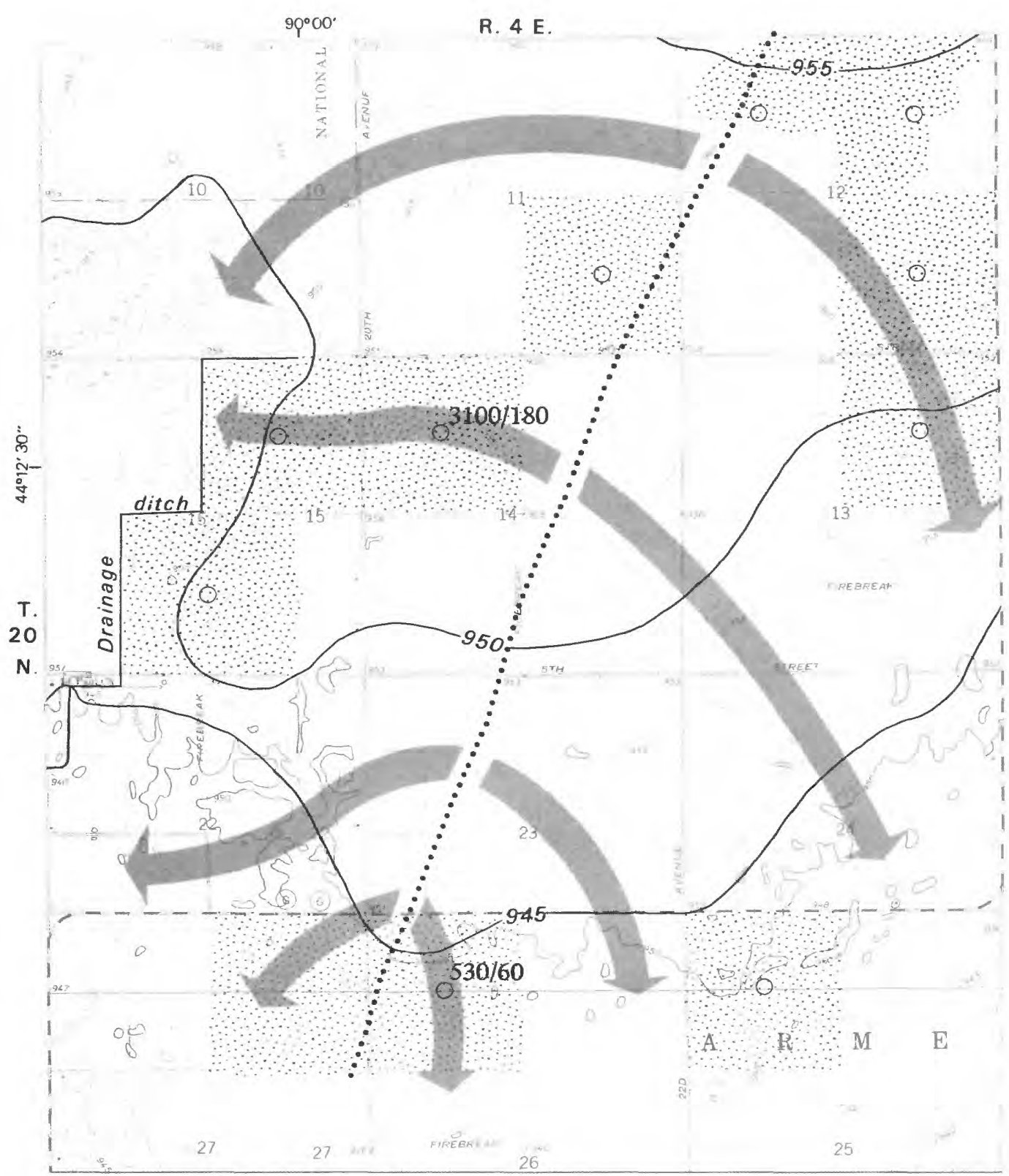

Base from U.S. Geological Survey

Arkdale,NW and New Miner 1:24,000, 1969

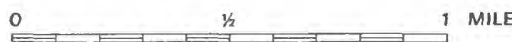

\section{EXPLANATION}

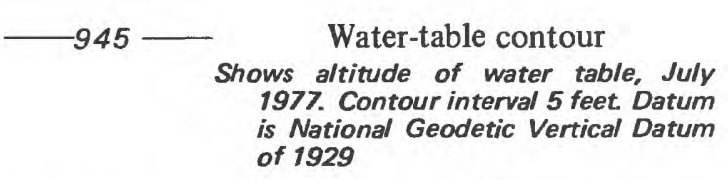

Ground-water divide

\section{$0^{530 / 60 \quad \text { Sampled irrigation well }}$ \\ Number indicates iron/manganese concentrations, respectively, in micrograms per liter}

Areas recently cleared for irrigation

Direction of ground-water flow

Water table in part of Armenia Township, Juneau County. 


\section{REFERENCES}

Bell, E. A., and Hindall, S. M., 1975, The availability of ground water for irrigation in the Rice Lake-Eau Claire area, Wisconsin: Wisconsin Geological and Natural History Survey Information Circular 31, $65 \mathrm{p}$.

Borman, R. G., and Trotta, L. C., 1975, Groundwater resources and geology of Jefferson County, Wisconsin: Wisconsin Geological and Natural History Survey Information Circular 33, 31 p.

Environmental Protection Agency, 1976, National interim primary drinking water standards: Washington, D.C., Environmental Protection Agency, Office of Water Supply, $159 \mathrm{p}$.

Hindall, S. M., 1978, Effects of irrigation on water quality in the sand plain of central Wisconsin: Wisconsin Geological and Natural History Survey Information Circular 36, $50 \mathrm{p}$.
State of California, 1963, Water-quality criteria: California State Water Quality Control Board, Publication 3-A, $548 \mathrm{p}$.

U.S. Geological Survey, 1977, Water resources data for Wisconsin-water year 1976: U.S. Geological Survey Water-Data Report WI-76-1, 609 p.

1978, Water resources data for Wisconsinwater year 1977: U.S. Geological Survey WaterData Report WI-77-1, 637 p.

Whitson, A. R., Geib, W. J., Dunnewald, T. J., and Hanson, L. P., 1918, Soil survey of Portage County, Wisconsin: Wisconsin Geological and Natural History Survey Bulletin 35, 664 p. 


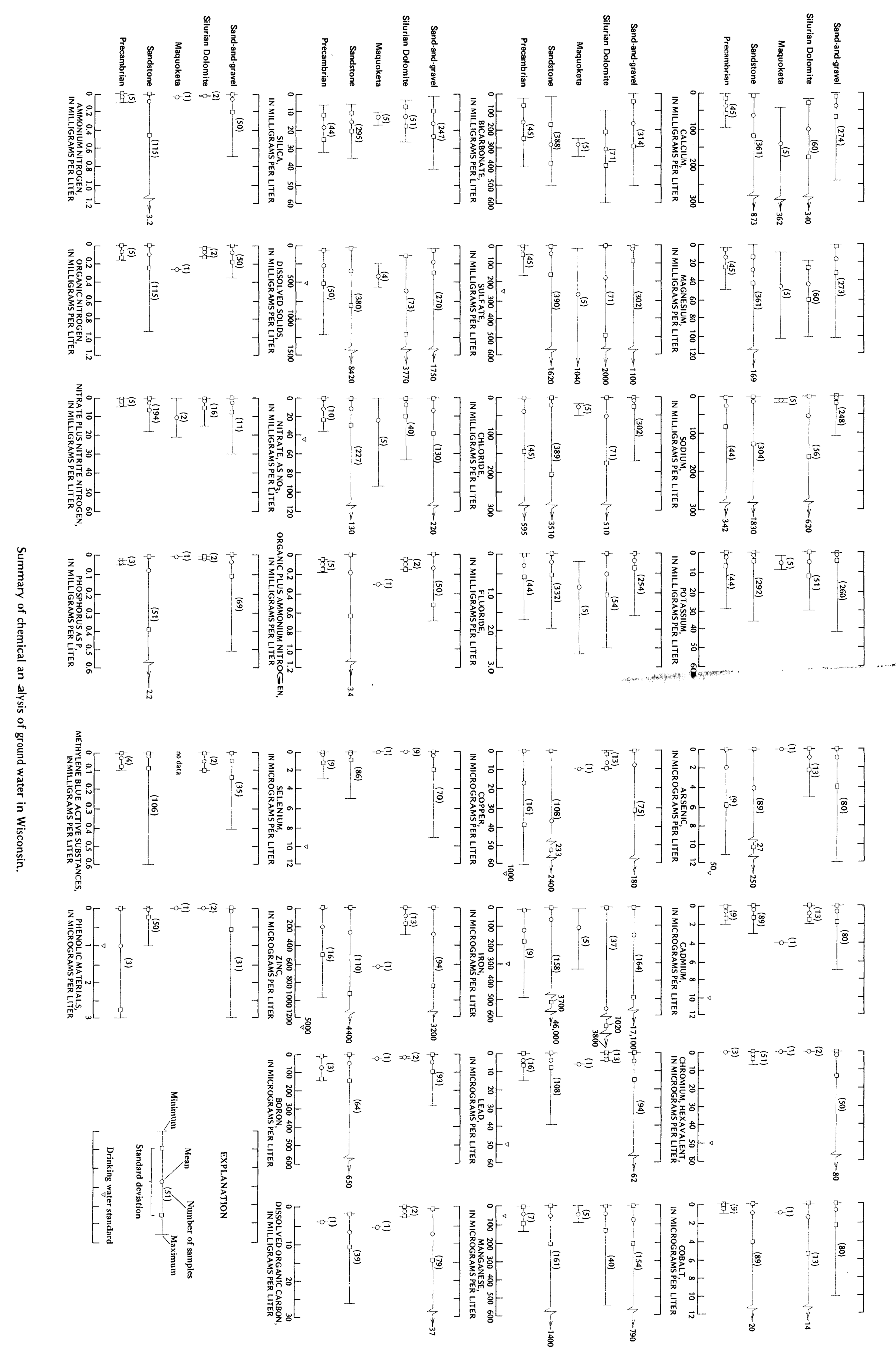

